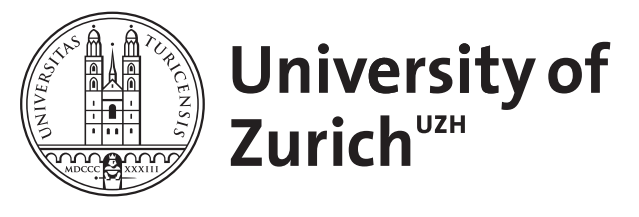

\title{
Was und wie hat Sokrates gewusst?
}

\author{
Ferber, Rafael
}

\begin{abstract}
The first part of the paper (p. 10-21) tries to answer the first question of the title and describes a set of seven "knowledge-claims" made by Socrates: 1. There is a distinction between right opinion and knowledge. 2. Virtue is knowledge. 3. Nobody willingly does wrong. 4. To do injustice is the greatest evil for the wrongdoer himself. 5. An even greater evil is if the wrongdoer is not punished. 6. The just person is happy; the unjust person is unhappy. 7. The pleasant is not the good. These claims seem to be the "few" (oliga) (Men. 98 b3) but "very important" (kallista) (Grg. 472 c8) things that Socrates claims to know. The second part (p. 22-39) tries to answer the second question and defends the thesis that the supposed "knowledge" of Socrates is dianoetic, but not noetic. The main new idea of this paper is the comparison of the Socratic knowledge-claims with the upper states of the mind symbolized in the Divided Line, noesis and dianoia (cf. R. 511 d7-e1).
\end{abstract}

Posted at the Zurich Open Repository and Archive, University of Zurich ZORA URL: https://doi.org/10.5167/uzh-3270

Journal Article

Published Version

Originally published at:

Ferber, Rafael (2007). Was und wie hat Sokrates gewusst? Elenchos, 28(1):5-39. 


\section{What did Socrates know and how did he know it?}

\section{Rafael Ferber}

In the first part of my paper I will try to answer the first question of the title and deal with a set of seven "knowledge-claims" made by Socrates. These claims seem to be the "few" (oliga) (Men. 98 b3), but rather "very important" (kallista) (Grg. 472 c8) things Socrates claims to know. In the second part I will try to answer the second question and defend the thesis that the supposed "knowledge" of Socrates is only dianoetic, but not noetic. The main new idea of this paper is the comparison of the socratic "knowledge-claims" with the upper states of the mind symbolized in the Divided Line, noesis and dianoia (cf. $R$. $511 \mathrm{~d} 7$-e1).

Because of limitations of space I can give here only a brief indication of the content of the first part and then go on to the second. Since so much has been written about Socrates he seems to have become rather a fleeting image in a labyrinth of mirrors. Therefore I may be forgiven to give here only an overall, if perhaps a simple, snapshot of this elusive figure and his apparently competing claims of "knowledge" and of "ignorance".

First I assume that the platonic Socrates maintains despite his disavowal of "knowledge" a central core of philosophically interesting "knowledge-claims". This central core seemed to him (and Plato) relatively immune to revision. Different people would formulate it in different ways. ${ }^{1}$ Very tentatively I formulate this core as follows:

1. There is a distinction between right opinion and knowledge.

2. Virtue is knowledge.

3. Nobody does willingly wrong.

4. To do injustice is the greatest evil for the wrongdoer himself.

5. An even greater evil is if the wrongdoer is not punished.

6. The just man is happy, the unjust person is unhappy.

7. The pleasant is not necessarily the good.

The first issue Socrates claims explicitly in the Meno as one (hen) of the few (oliga) things he knows, "if I would claim to know anything" (eiper ti allo phaien an eidenai) (98 b3). ${ }^{2}$ The other ones seem to him "held down and bound by arguments of iron and

\footnotetext{
${ }^{1}$ Cf. now the paper of Wolfsdorf (2004), 102: "In sum, Socrates claims or presumes to know or implies knowing the following propositions: Good men are just. Socrates has done no wrong. Hippocrates has courage. It is wrong to commit injustice by disobeying a superior, whether god or man. The craftsmen know many fine things. What excellence is." I am not able to see much philosophical interest in most of these knowledge-claims of Wolfsdorf's Socrates. I have put the above "knowledge-claims" into quotation marks because, as T. Penner has reminded me, Socrates does not explicitly say that he knows all these propositions (1) to (7), although he claims explicitly to know (1) and (2). Nevertheless to avoid a purely verbal dispute we may pretty well assume that he believes in the truth of the propositions (3) to (7) because of an aitias logismos (Men. 98 a3) and can claim insofar to have by his own standards a kind of knowledge of these propositions.

${ }^{2} \mathrm{Ch}$. Rowe reminds me of the allo. But with Schleiermacher, Apelt, Rufener, Sharples and others I may be forgiven not to translate allo, since the translation "If I would claim to know anything else" would suggest that Socrates
} 
adamant, even if it is rather rude to say" (Grg. 508 e 7-509 a). On the other hand, Socrates affirms in the Meno: "For I myself do not have the answer when I perplex others, but I am more perplexed than anyone when I cause perplexity in others. So now I do not know what virtue is" (Men. $80 \mathrm{c} 8$-d1. Grube's tr.). An analogue confession of ignorance we find also in the Gorgias: "For the things I say I certainly don't say knowingly: no, I'm searching together with you so that if my opponent has a point, I'll be the first to concede it" (Grg. 506 a3-5; cf. Euthphr. 16 d; Hi.Ma. 304b-c). And later on Socrates says: "And yet for my part, my account is ever the same: I don't know how these things are" (Grg. 509 a4-5).

The problem is therefore the following: How could Socrates affirm the propositions (1) to (7) and nevertheless say that he "does not know how these things are"?

Two answers have already been refuted by Vlastos in his well known article Socrates' disavowal of knowledge (1985), which is anticipated in his introduction to the Protagoras $(1956)^{3}$ : One is that the alleged knowledge of Socrates is to be taken ironically, ${ }^{4}$ the other one that Socrates is defending with his knowledge-claims only his true opinions. ${ }^{5}$ I think that Vlastos is right on both issues. If the alleged knowledge of Socrates is to be taken ironically in its simple sense (and therefore is not knowledge, but only opinion) Socrates' ignorance would be fictitious; and Socrates would cheat his interlocutors and not say the truth in contrast to what he tells us since the Apology (cf. 20 d). If the socratic knowledge would only be true opinion, Socrates would not have to give arguments "of iron and adamant" for his opinions, or his arguments would be disguised rhetorical tricks. Socrates would then be just a sophist and his distinction between dialectic and rhetoric (cf. Grg. 454e-455a) would collapse.

Vlastos tried to solve the problem by distinguishing a dual use of Socrates' words for knowing, knowing in the sense of certainty, and knowing in the sense of having survived an elenchus:

To resolve the paradox we need only suppose that he is making a dual use of his words for knowing. When declaring that he knows absolutely nothing he is referring to that very strong sense in which philosophers had used them before and would go on using them long after - where one says one knows only when one is claiming certainty. This would leave him free to admit he does have moral knowledge in a radically weaker sense - the one required by his own maverick method of philosophical inquiry, the elenchus. ${ }^{6}$

Nevertheless Vlastos' solution came under fire from different angles. I mention two:

On the one hand it seems improbable that Socrates who insists on the unity of the definiendum is distinguishing between two different meanings of the word "knowledge". ${ }^{7}$ On the other hand it has been said that Socrates is distinguishing between expert knowledge and non-expert knowledge, but does not claim for his ethical knowledge the status of expert knowledge or a skill. Socrates is not an expert in ethics because he has no special ethical skills. $^{8}$

Both proposals seem to me not to be convincing. If Socrates has not yet found this unitary definition of "knowledge", he is not able to use the word in this unitary way. In fact

knows that there is a distinction between right opinion and knowledge and where it lies. In fact he knows only that there is a distinction. Cf. Sharples (1984), 185: "In either case ti allo in b3, literally 'anything else' is best rendered in English by an emphatic 'anything', 'anything at all'; one may compare allos te ... kai = 'especially' (see above, on 94 c3)."

${ }^{3}$ Cf. the critical note of Dodds (1959), 16, n. 2.

${ }^{4}$ So Gulley (1968), 69. Cf. contra Vlastos (1994a), 40-42.

5 So Irwin (1977), 39-40. Cf. contra Vlastos (1994a), 42-48; cf. also Benson (2000), 176-188.

${ }^{6}$ Vlastos (1994a), 49.

${ }^{7}$ Cf. Lesher (1987).

${ }^{8}$ Cf. Woodruff (1992), esp. 90-91. 
since the Apology Socrates uses the word oida ambiguously, i.e. in a strong and in a weaker sense, e.g. also in the sense of right opinion: "And yet I know pretty well (schedon oida) that I am making myself enemies by just that conduct: which is also a proof that I am speaking the truth" (Ap. 24 a6-7). And: "For well I know (eu oida) that wherever I go, the young men will listen to my talks, as they do here" (Ap. 37 d6-7). Socrates uses the word oida also in an ordinary sense like his contemporaries, where the word has hardly its emphatic and nondoxastic meaning, but rather the meaning of right opinion. But evidently also in the ordinary use of the word it is used in a stronger and weaker sense and with qualifications. Socrates knows for example "barely" (schedon), "well" (eu), or "not enough" (ouk hikanos) (cf. Ap. 24 a6. 37 d6. 29 b5). Evidently there are degrees of belief even in the ordinary meaning of the word oida as used by Socrates.

But the philosophical point of the alleged "knowledge" and "ignorance" of Socrates seems to me that with these ambiguities it has not yet been explained. In the same way, the distinction between knowledge, in the sense of a craft or skill, and ethical knowledge seems to me not to hit the nail on the head. Socrates starts to prove his proposition (2) "virtue is knowledge" in the Gorgias from the model of expert knowledge or expert skills (Grg. 460 a5b6); but he does not distinguish explicitly between "knowledge" in the sense of ethical knowledge and expert skill.

But since the Apology he distinguishes explicitly between human and divine wisdom (cf. Ap. 23 a). However if the propositions (1) to (7) are truths, they cannot be refuted. They remain as certain or infallible as truths can be: "For the truth gets never refuted" ( $\mathrm{Grg} .473 \mathrm{~b}){ }^{9}$ If infallibility is the mark of divine knowledge, the knowledge of Socrates would then be divine knowledge, and the difference in the dual meaning of the word "knowledge" - elenctic or fallible knowledge, which Socrates has, and certain or infallible knowledge, which God has - would disappear. But is there not also infallible human knowledge as Socrates affirms of his truths (1) to (7), at least as long as the meanings of the expressions are maintained by the conventions in a homologia?

The decisive philosophical point seems to me to be the following. The truths (1) to (7), or at least (2) to (7), which seem to him "held down and bound by arguments of iron and adamant", fulfil the criterion of coherence or consistency. But if we accept coherence or consistency as a criterion of truth, the following question still remains open: A proposition or a system of propositions may be coherent, but is it true? ${ }^{10}$ This means: the propositions (1) to (7) may survive the elenchus and be homologoumena. But are they also true? It is logically possible that they have survived an elenchus, but are nevertheless not true, but false (i.e. contrary to being, cf. Sph. 240 d). To assert their truth we need an external criterion of truth which transcends the consistency reached by an elenchus and would imply correspondence with being, and this means for Socrates/Plato correspondence with an ideal reality. In fact Socrates/Plato assumes not only a coherence-, but also a correspondence-theory of truth and a non correspondence-theory of falsehood.

But to affirm a correspondence between the propositions (1) to (7) and their ideal counterparts we have to know the propositions (1) to (7) and independently their counterparts. Only in this way we may decide whether the propositions (1) to (7) mirror their counterparts or not. We need an objective instance or God's eye view. The correspondence theory of truth presupposes God's eye view.

In fact the ultimate criterion of truth for Plato from the Apology to the Timaeus is not consistency, but the knowledge which God has "who is in fact wise" (Ap. 23 a5-6;

\footnotetext{
${ }^{9}$ Cf. for the analytical character of e.g. proposition (2) my paper (1991).

${ }^{10} \mathrm{Cf}$. my critique of the coherence- and consensus-theories of truth (2003), 96-97, 99-101, 103-104.
} 
cf. Ap. 42 a3), i.e. he has the best possible knowledge we can think of. So says Socrates after his interpretation of the simile of the cave: "God may know, if my hope is true" (R. 517 b6-7; cf. Phd. $69 \mathrm{~d} 4-6)$ and then Timaeus concerning his opinions on the soul: "If God acknowledges (theou symphesantos) that we have spoken the truth, then, and only then, can we be confident" (Ti. 72 d5-6. Jowett's tr. with a small alteration from R.F.).

As regards Socrates this means in my opinion the following: If we measure the knowledge of Socrates, reached by an elenchus, on the knowledge of God, Socrates' knowledge-claims remain provisional. This does not mean that they are proved to be false anywhere in the dialogues, but that they have to be done away as assumptions (hypotheseis): "So, said I, the method of dialectic is the only one which takes this course, doing away with assumptions (tas hypotheseis anairousa) and travelling up to the first principle of all, so as to make sure of confirmation there" (R. 533 b. Cornford's tr.). What is said here from mathematical hypotheseis seems to me probably to apply also to the ethical propositions (2) to (7) and especially to the ethical proposition (6) that "the just man is happy and the unjust person is unhappy". To prove this proposition again, Plato wrote the Republic after the Gorgias. As long as these propositions do not correspond with an ideal reality and are not reduced to their origin, the non-hypothetical principle or idea of the Good, the homologia reached between Socrates and his interlocutors is not yet an episteme: "If your premise is something you do not really know and your conclusion and intermediate steps are a tissue (sympeplektai) of things you do not really know, your reasoning may be consistent with itself (homologia), but how can it amount to knowledge (episteme)?" (R. 533 c5-6. Cornford's tr. $)^{11}$ What is said here from mathematical hypotheseis, which the mathematicians laid down "as known" (R. $510 \mathrm{c} 6)$ and treat as absolute or non-hypothetical assumptions, seems to me valid also of the ethical propositions (2) to (7) or at least of the ethical assumption (6) "The just is happy and the unjust is unhappy"; also these propositions seem to be laid down "as known". Knowledge by dialectic in the Republic means for Plato synagoge of all mathematical hypotheseis and, as we may assume, also ethical ones like the proposition (6) to the Idea of the Good and dihairesis from the idea of the Good. Only in this way the definitional ignorance of Socrates can, like the definitional ignorance of the mathematicians, be overcome. This is a gigantique or "huge project" (sychnon ergon) $(R .511 \mathrm{c} 3)$ to which the simile of the line and cave allude, but which is not completed in the Republic or elsewhere in the written work. What the "socratic knowledge-claims" (1) to (7) or at least (2) to (7) lack is not infallibility. It is rather, from the platonic perspective, their connection to and unfolding from their origin. ${ }^{12}$

In other words: As well as the geometrical propositions express a dianoetic, but not yet a noetic knowledge (cf. $R .533 \mathrm{~d} 5$ ), which is "brighter than doxa, but darker than episteme" ( $R .533 \mathrm{~d} 5$ ), in the same vein the knowledge of Socrates expressed by the propositions (1) to (7) seems to be "brighter than doxa, but darker than episteme". In fact already the first knowledge-claim "There is a distinction between right opinion and knowledge" is presented by Socrates in a hypothetical way: "if I would claim to know anything" (eiper ti allo phaien an eidenai) (98 b3), then "I" would claim that there is a "distinction between right opinion and knowledge" (cf. 98 b2); the other ones (2) to (7) are homologoumena between Socrates and his interlocutors. Homologoumena are conditioned by the homologia of the interlocutors. (2) to (7) are therefore also conditional truths. So we may say of all the seven socratic

\footnotetext{
${ }^{11}$ Homologia may mean consensus or consistency. Cf. the remarks to homologoumenos, R. 510 d2, in: Ferber (1989), 96, where I plea rather for consensus. Maybe homologia means here a consistent consensus.

${ }^{12}$ For the details of this project cf. Ferber (1989), 97-111, 178-188, 206-211, and now Fine (2003), esp. 109-111. For the definitional ignorance cf. also Chrm. 165 b-c.; Lach. 200 e; Men. 71 a, b; R. 337 d-e. 354 b-c; Hipp. mai. 286 c-e. 304 d-e; Lys. 223 b.
} 
"knowledge-claims" that they are like the "knowledge-claims" of the mathematicians conditional knowledge-claims or hypotheseis. In fact in the Theaitetos (155 b4) the axioms of the mathematicians are explicitly called homologemata (cf. Grg. 480 b3).

We may now solve the contradiction between Socrates' apparently competing claims of "ignorance" and "knowledge" in the following way. When Socrates says that he "does not know how these things are", he does not have an episteme of the propositions (1) to (7). When he nevertheless says that these issues seem to him "bound and held down by arguments of iron and adamant" he knows these homologies in a sense similar to the dianoia of the mathematicians. Probably he wanted to gain moral knowledge with the method of hypothesis (cf. Men. 87 c5) similar in certitude to mathematical knowledge.

For those who may not agree I may weaken my point a little with the words of Socrates: "And a man must take with him to the house of death an adamantine doxa in this [...]" ( $R .618$ e4-619 a1) i.e. in proposition (6) "that the just man is happy, the unjust person unhappy". ${ }^{13}$ But an adamantine doxa, besides being perhaps an allusion to Plato's brother Adeimantos, means pretty well a doxa which is "held down and bound by arguments of iron and adamant" (Grg. 508 e7-509 a1). It is at least a "stable doxa" (doxa monima) (cf. Men. 98 a6). It is still for the Athenian in the Laws as clear as the statement "Crete is obviously an island" (Leg. 662 b3-4). The negation of this statement, "Crete is not an island", is an empirical falsehood. The negation of proposition (6) "The just man is happy", i.e. "The just man is not happy", is a conceptual one (cf. Leg. 662 e9). But the status of a doxa so clear that its negation is a conceptual falsehood seems to me barely distinguishable from the status of dianoetic knowledge. It is at least dianoia-like and "adamantine" or very solid i.e. very examined knowledge.

In other words: The propositions (1) to (7) contain for Socrates or Plato knowledge and not only fallible knowledge, but certain or infallible knowledge. But they do not contain a noesis or synoptic understanding (cf. $R .537 \mathrm{~b} 7$ ) or comprehension how to be connected with their origin, and how to be derived from their origin, and where to be interwoven in the whole web of the dialectician's thought. Nevertheless these propositions like the mathematical hypotheseis are only understandable (noeta) with their origin (met'arches) $(R .511 \mathrm{c} 3$ ).

In fact today in a context influenced by Kant in which many philosophers separate the just from the good and are seeking for the just another origin than the Good, the principle of universalisability, many of us would understand some of the propositions (2) to (7) in another way. So many philosophers would say with Kant instead of saying simpliciter with Socrates (6) "The just man is happy, the unjust person is unhappy", "the just man is morally happy, but not necessarily physically", "the unjust person is morally unhappy, but not necessarily physically". Instead of (7) "The pleasant is not necessarily the good" they would say, "The pleasant is not necessarily the morally good". But this is quite another story. ${ }^{14}$

\section{Luzern / Zürich}

\footnotetext{
${ }^{13}$ I owe the reference to "adamantine faith" to M. Burnyeat.

${ }^{14} \mathrm{Cf}$. for the distinction between physical and moral happiness Kant : The Religion Within the Limits of Reason Alone, B 86, B 100, footnote. My sincere thanks go to David Longrigg for the improvement of my English and lic. phil. Thomas Hiltbrunner for some helpful remarks.
} 